\title{
CONSERVATION ISSUES AND INFRASPECIFIC POLYMORPHISM OF CYPRIPEDIUM GUTTATUM ON SELECTED LOCATIONS IN RUSSIA
}

\author{
Alexander I. Shirokovi,*, Vera V. Syrova', Alexey V. Salokhin ${ }^{2}$, \\ Ivan N. Markelov ${ }^{1}$, Elena V. Andronova ${ }^{3}$, Elena V. Ganyushkina ${ }^{1}$ \\ ${ }^{1}$ Lobachevsky State University of Nizhny Novgorod, Russia \\ *e-mail: aishirokov@mail.ru \\ ${ }^{2}$ Botanical Garden-Institute FEB RAS, Russia \\ e-mail:al-xv@mail.ru \\ ${ }^{3}$ Komarov Botanical Institute of RAS, Russia \\ e-mail: elena.andronova@mail.ru
}

Received: 14.04.2020. Revised: 22.08.2020. Accepted: 01.09.2020.

\begin{abstract}
The problem of protection and conservation of rare and endangered plant species in the wild is currently the topic of discussion and research worldwide. The Orchidaceae plants are of special concern. Orchids are so well adapted to their environments. Moreover, they have special requirements that makes it difficult to transplant them from the wild and they are rarely surviving after. They are therefore a key group in conservation. This research aimed to study the polymorphism of Cypripedium guttatum flowers in their natural populations on selected locations in Russia. On the basis of studying C. guttatum populations in Primorsky Krai, Sverdlovsk region, Komi Republic, and Krasnoyarsky Krai, we identified and described five forms of $C$. guttatum in terms of their flower colouration. A comparison study of the infraspecific structure revealed that the form variation in the studied C. guttatum populations was the highest in Primorsky Krai and the lowest in Sverdlovsk region. A discriminant analysis indicated the following statistically significant morphometric parameters to recognise different forms of C. guttatum: shoot height, leaf width, flower width, height and width of dorsal sepal and staminode width. A population variation analysis was conducted with respect to the following three indicators: the average number of morphs per population, the rare morph ratio in the population, and the similarity index of the studied populations. On the basis of monitoring $C$. guttatum populations and studying their infraspecific structure, as well as the biology and ecology of this threatened orchid species, we developed a specific conservation project for rare and endangered orchid species complying with the unique biology of these plants.
\end{abstract}

Key words: flower colouration, discriminant analysis, morphometric parameters, monitoring, Orchidaceae, rare species, specific project

\section{Introduction}

Under contemporary conditions of intensified technological processes and negative anthropogenic impact on the environment, the protection and conservation of rare and endangered orchid species is a very serious problem. The plants belonging to the family Orchidaceae are protected by the Red Data Books and Conventions on different levels (Kopowitz, 2005; Red Data Book of the Russian Federation, 2008; Feldmann \& Prat, 2011; Swarts \& Dixon, 2017; Fay, 2018). Orchids are among the most threatened plants in Russia as they are highly dependent on environmental conditions. There are five Cypripedium species native in Russia: Cypripedium calceolus L., Cypripedium guttatum Sw., Cypripedium macranthos Sw., Cypripedium shanxiense S.C.Chen, and Cypripedium yatabeanum Makino, and four hybrids (Cypripedium $\times$ ventricosum Sw., Cypripedium $\times$ alaskanum $\mathrm{P} . \mathrm{M}$.Br., Cypripedium $\times$ catherinae Aver.) (Averyanov, 1999; Salokhin, 2009; Vakhrameeva et al., 2008; Li et al., 2011). Among orchids, the genus Cypripedium is one of the most stunning (highly prized ornamental flowering plants) and at the same time the most threatened (being at risk of extinction) (Cribb \& Sandison, 1998; Cribb at al., 2003; Kolanowska \& Jakubska-Busse, 2020).

The recognising of infraspecies taxa (varieties, forms) is one of the important tasks of current taxonomy and plant population biology since they make it possible to assess the species diversity both in local populations and within the whole range (Stuessy, 2009; Hardion et al., 2017). This is especially urgent for rare and endangered plant species. They require not only assessment, but also implementation of relevant conservation actions, such as reintroduction, artificial propagation and cultivation (Thomson et al., 2018).

Cypripedium guttatum is characterised by a high variability in their morphological characters. Of them, polymorphism of the flower colouration is the most significant. Despite numerous attempts, only one form of $C$. guttatum $\mathrm{f}$. albiflorum Aver. was recognised and described (Averyanov, 1999, 2000). 
This form is characterised by the purely white flowers and brightly yellow staminode. It is distributed from the Urals throughout Siberia. In the highlands of China Cypripedium individuals with white-yellow flowers without any spots has been described and recognised as a new species, C. bouffordianum (Zhang \& Sun, 2006). However, currently, this name is used as a synonym of C. guttatum (Zhengyi et al., 2009; Singchi et al., 2013).

At present, in Eastern Siberia and the Russian Far East, C. guttatum is still represented (Salokhin, 2018). However, orchid hunters collect the endangered orchid for illegal international trade even in these remote areas. Identification and analysis of the infraspecific diversity and distribution of the Cypripedium representatives is a priority task before conservation measure application.

The aim of the present research was to study the polymorphism of Cypripedium guttatum flowers in its populations on some selected locations in Russia. The study included several tasks. At first, we focused on C. guttatum populations to reveal individuals with various flower colouration and assess their distribution on the selected locations in Russia. Secondly, we measured and analysed morphometric parameters of the vegetative and generative organs of individuals to detect the most significant plant morphological characters to confirm the validity of the identified forms using discriminant analysis. Finally, we developed a set of strategies to protect the $C$. guttatum populations.

\section{Material and Methods}

Cypripedium guttatum is the object of our study. This orchid species is native to Belarus, Russia (European Russia, Siberia, Russian Far East), China, Korea, Mongolia, Bhutan, Alaska (including Aleutian Islands), North Canada (Yukon and Northwest regions) (Cribb, 1997; Averyanov, 1999; Flora of North America North of Mexico, 2002; Zhengyi et al., 2009).

Cypripedium guttatum is morphologically characterised as follows. Rhizomes are thin, slightly branching, stolon-like, with internodes (2) $4-7(10) \mathrm{cm}$ long. There are numerous roots at the nodes. Stems together with the peduncle are (8)12-30(35) cm high. There are two close subopposite leaves in its middle or lower part. Leaves are elliptic, ovate, (4.5)5-11(13) cm long and (2)2.5$5(6) \mathrm{cm}$ wide. Inflorescence is terminal, with one flower. Peduncle is (4)5-12(14) cm. Floral bracts are foliaceous, ovate-lanceolate, (1.5)2-3(3.5) cm long, 0.6-1.4(1.6) $\mathrm{cm}$ wide. Apex is acute or acuminate. Veins are sparsely pubescent. Ovary is sessile on a short pedicel, arcuate, densely pubescent and glandular hairy, 0.7-1.4 (1.8) cm long and 1.5-2 mm thick. Sepals are white with large irregular merging purple-pink, brownish-pink or rarely greenish-brown spots (sepals and lateral petals are whitish outside). Dorsal sepal is antrorse, ovate or elliptic-ovate, (1.3)1.6-2.5(2.7) $\mathrm{cm}$ long and (1)1.2-1.8(2.2) cm wide. Synsepal is narrowly ovate or elliptic, (0.9)1.0-1.5(1.6) $\mathrm{cm}$ long, $0.4-0.6 \mathrm{~cm}$ wide. Lateral petals are directed to the sides and slightly forward from an unequally wide base gradually tapering into a rounded, obtuse tip, (1.2)1.3-2.0(2.1) cm long and $0.6-0.7(0.8) \mathrm{cm}$ wide, glabrous. Lip is shortly narrowed at the base, cyathiform at the tip, with a wide orifice, lacking an incurved apical margin, (1.4)1.6-2.2(2.3) $\mathrm{cm}$ long and 1.0-1.3(1.6) $\mathrm{cm}$ wide, shorter than or equalling the dorsal sepal. Column and anthers are yellowish-white. Staminode is yellowish, arched. Stigma is broadly ovate, indistinctly 3-lobed. Flowering period is June to July (Averyanov, 1999). The research was conducted in 2014-2019 in different parts of the range of Cypripedium guttatum in Russia (Fig. 1).

To identify polymorphic groups of Cypripedium guttatum, their flowers were assessed for monochromatic or spotted colouration, and the pattern of the markings. According to the flower colouration, we distinguished the following five forms: C. guttatum f. guttatum, $C$. guttatum f. rubrosaccos nom. prov., C. guttatum f. albostriatum nom. prov., C. guttatum f. externemaculatum nom. prov., C. guttatum f. semialbum nom. prov. It should be emphasised that all these newly used names for forms of Cypripedium guttatum in this article are nom. prov., nomen provisorum, i.e. a preliminary name of a taxon, whose valid description will be published in the nearby future. Then, we performed a morphometric analysis of the studied populations to prove the validity of the identified $C$. guttatum forms. The following significant morphometric parameters were analysed: plant height, height and width of the solitary flower, length and width of leaves, bracts, dorsal sepals, lateral petals, lips, staminodes, and the diameter of the lip orifice. The total amount of morphometrically analysed individuals was 210 . Of them, 80 individuals were collected in Primorsky Krai, 60 in Krasnoyarsky Krai, 40 in the Komi Republic, 30 in Sverdlovsk region. 


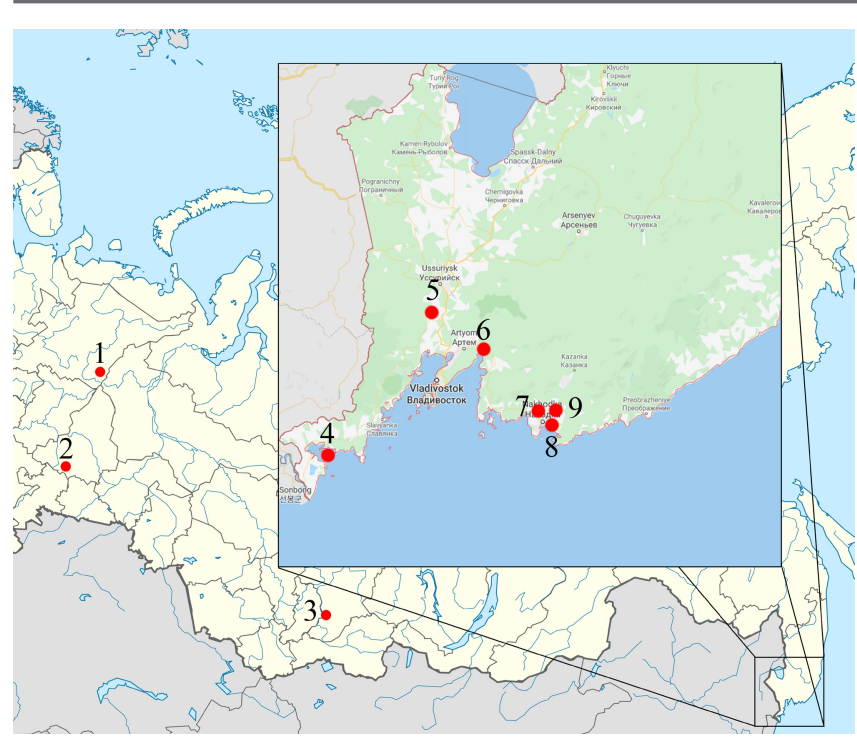

Fig. 1. Location of the Cypripedium guttatum populations studied in Russia. Designations of Russian regions: 1 - Komi Republic; 2 - Sverdlovsk region; 3 - Krasnoyarsky Krai; 4-8 Primorsky Krai.

The analysis of the population variation was conducted in terms of the following three indicators: the average number of morph types per population $(\mu)$, the rare morph ratio in the population (h) (Table 2), and the similarity index of the studied populations (r). The indicators of infrapopulation variation were calculated according to Zhivotovsky (1982):

- average number of morphs in the population: $\mu=\left(\sqrt{p_{1}}+\sqrt{p_{2}}+\ldots+\sqrt{p_{m}}\right) \times 2$;

- statistical error: $s_{\mu} \approx \frac{\sqrt{\mu(\mu-m)}}{N}$;

- rare morph ratio in the population: $h=\frac{1-\mu}{m}$;

- pairwise index of the population similarity:

$$
r=\sqrt{p_{1} q_{1}}+\sqrt{p_{2} q_{2}}+\ldots+\sqrt{p_{m} q_{m}},
$$

where $p$ is the frequency of the phenotypes in the first population, and $q$ is the frequency of the phenotypes in the second population, and $m$ is the number of phenotypes, $N$ is the sampling size.

On the basis of these morphometric parameters, we conducted a discriminant analysis. A cluster analysis was carried out using the index of the population similarity (r) and was constructed using the Ward method (Ward, 1963). The discriminant and cluster analysis was performed using the STATISTICA 10 software package. Statistical significance was confirmed by the F-test.

\section{Results \\ Morphological description of Cypripedium guttatum forms}

We determined a number of Cypripedium guttatum forms in its populations in terms of the flower colouration. Cypripedium guttatum f. guttatum represents the typical form with spots evenly distributed over the lip and inner side of the dorsal sepal and lateral petals (Fig. 2A). Cypripedium guttatum f. rubrosaccos nom. prov. differs by an even purple lip colouration and spotted dorsal sepal and lateral petals (Fig. 2B). Cypripedium guttatum f. albostriatum nom. prov. represents a form with a red-coloured lip with a distinct white stripe in the middle (Fig. 2C). Cypripedium guttatum f. externemaculatum nom. prov. is a form similar to C. guttatum f. guttatum but with distinct spots on the outer side of the dorsal sepal, whereas the outer side of dorsal sepal in other forms is completely white (Fig. 2D). Cypripedium guttatum f. semialbum nom. prov. is a transitional form between $C$. guttatum f. albiflorum and the typical C. guttatum f. guttatum. This is manifested in extremely pale spots on completely white petals of the flower (Fig. 2E).

\section{Determination key to the Cypripedium guttatum forms}

1. Flower has a pronounced spotting. .2

- Spots on the flower are barely visible or absent. .5

2. Spots on the lip are clearly delineated, the pattern is well defined.................................................3

- Spots on the lip merge; the colouration of the lip is more or less uniform........................................4

3. Spots are evenly distributed over the lip and inner side of dorsal sepal and lateral petals. The outer side of the dorsal sepal is white, without spots.

C. guttatum f. guttatum

- The outer side of the dorsal sepal has a pronounced spotting

C. guttatum f. externemaculatum nom. prov.

4. The lip is almost evenly purple-coloured

C. guttatum f. rubrosaccos nom. prov.

- A white vertical stripe in the middle of the lip divides it into two halves.

C. guttatum f. albostriatum nom. prov.

5. There are obscurely pale spots on the completely white petals of the flower. 

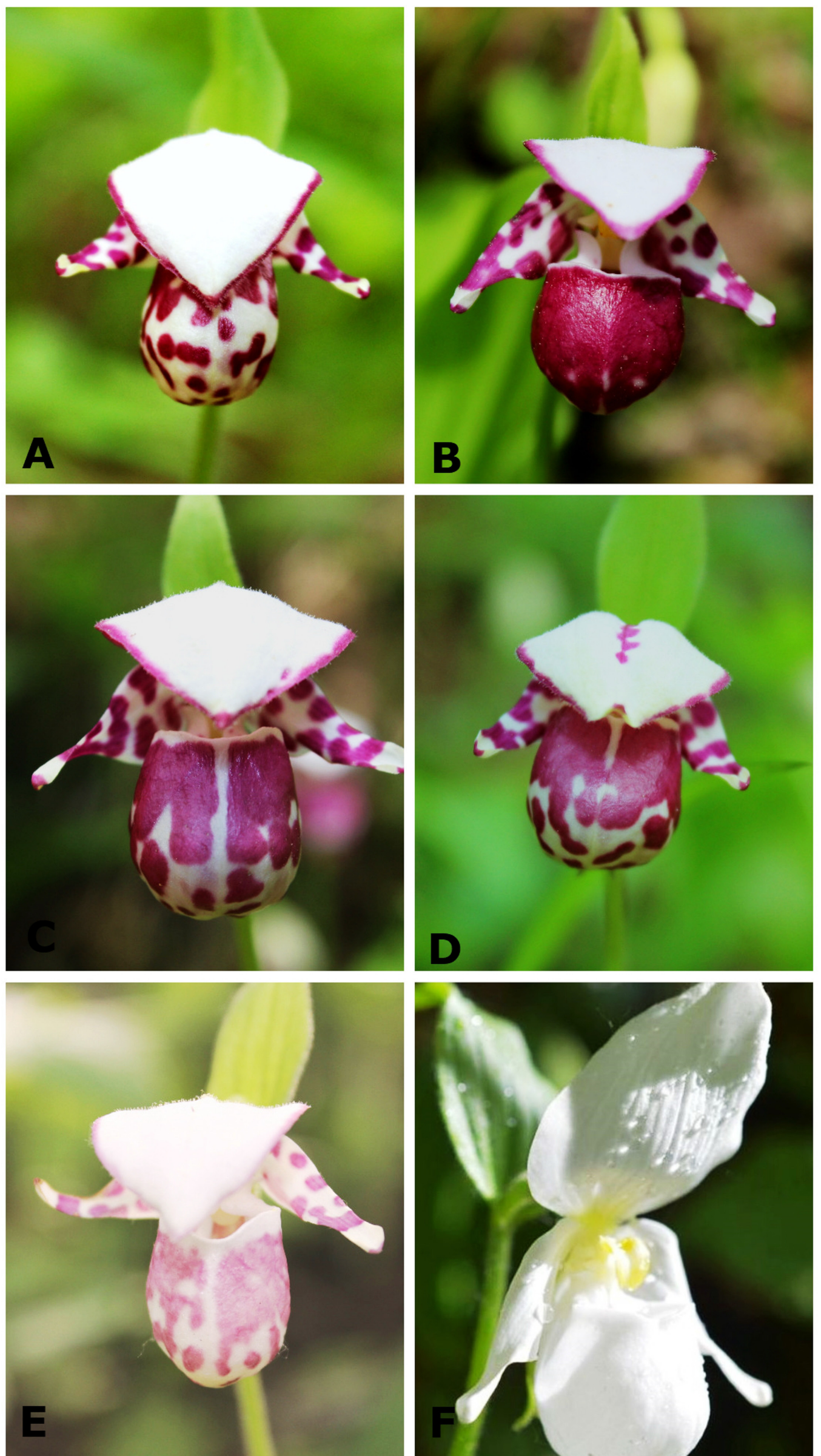

Fig. 2. Different forms of Cypripedium guttatum. Designations: A - C. guttatum f. guttatum; B - C. guttatum f. rubrosaccos nom. prov.; C - C. guttatum f. albostriatum nom. prov.; D - C. guttatum f. externemaculatum nom. prov.; E - C. guttatum f. semialbum nom. prov.; F - C. guttatum f. albiflorum. 
Infraspecific structure of the studied Cypripedium guttatum populations

The comparison study of the infraspecific structure of the studied populations revealed that variation in forms is noticeably higher in Primorsky Krai. All five identified forms of Cypripedium guttatum (C. guttatum f. guttatum, C. guttatum f. rubrosaccos nom. prov., C. guttatum f. albostriatum nom. prov., $C$. guttatum f. externemaculatum nom. prov., C. guttatum f. semialbum nom. prov.) are known in this region (Fig. 3). Only three forms $(C$. guttatum f. rubrosaccos nom. prov., C. guttatum f. albostriatum nom. prov., C. guttatum f. externemaculatum nom. prov.) are common in Sverdlovsk region. There are four forms $(C$. guttatum $\mathrm{f}$. guttatum, C. guttatum f. rubrosaccos nom. prov., C. guttatum f. albostriatum nom. prov., C. guttatum f. externemaculatum nom. prov.) found in the Komi Republic and Krasnoyarsky Krai (Fig. 3). The obtained data allow us to characterise Cypripedium guttatum as a species with a high infraspecific variation in colour.

Our study has revealed that the $C$. guttatum flowers have a different degree of spotting and brightness/colouration. For example, C. guttatum f. rubrosaccos nom. prov. has an almost evenly coloured purple-red lip. Cypripedium guttatum $\mathrm{f}$. albostriatum nom. prov. flowers are predominantly red with a white stripe dividing the lip. Cypripedium guttatum f. guttatum and C. guttatum f. externemaculatum nom. prov. flowers have a spotted pattern. Thus, unique colour patterns can be found in orchid populations to distinguish C. guttatum forms. It is possible that these forms can replace each other during the flowering period. In populations of the studied locations we identified a different number of forms. Moreover, in Cypripedium guttatum populations, the form variation was the highest in Primorsky Krai and the lowest in Sverdlovsk region. Cypripedium guttatum f. externemaculatum nom. prov. individuals prevailed in Sverdlovsk region populations, whereas they were not common in other regions. Cypripedium guttatum f. albostriatum nom. prov. dominated in populations in Krasnoyarsky Krai. Statistical significance of the percentage of C. guttatum f. externemaculatum nom. prov. and C. guttatum f. albostriatum nom. prov. in the study populations was confirmed by the F-test. According to the obtained data, this parameter was more than $2.64(\mathrm{p}<0.01)$. Unfortunately, in our research, we did not identify Cypripedium guttatum f. albiflorum individuals with white or yellow-white flowers lacking spots.

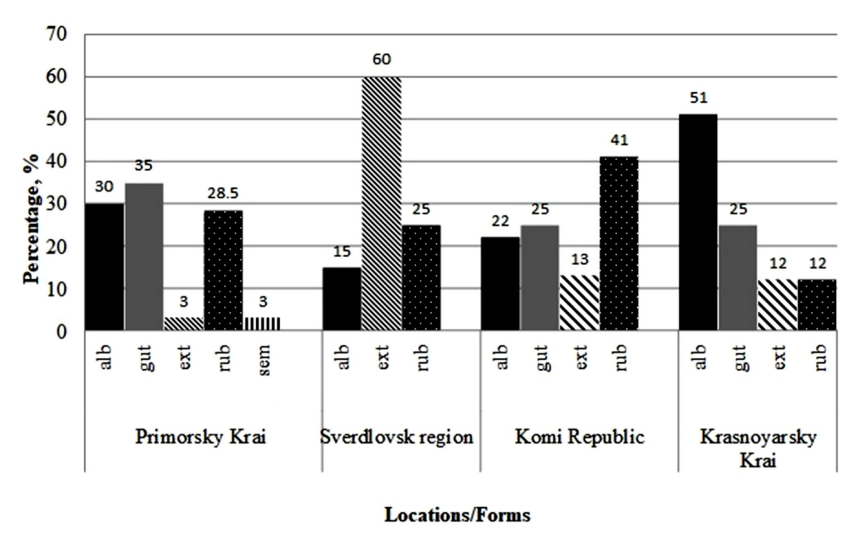

Fig. 3. The ratio of $C$. guttatum forms in the studied populations in each Russian region. Designations: alb $-C$. guttatum $\mathrm{f}$. albostriatum nom. prov.; gut - C. guttatum f. guttatum; ext $-C$. guttatum f. externemaculatum nom. prov.; rub-C. guttatum f. rubrosaccos nom. prov.; sem $-C$. guttatum $\mathrm{f}$. semialbum nom. prov.

\section{Results of discriminant analysis}

The average values of the main morphometric parameters of Cypripedium guttatum individuals are presented in Table 1 . We present them for populations in Primorsky Krai, where the highest population size and infraspecific phenotypic variation were found.

To determine statistically significant morphometric parameters, we performed a discriminant analysis of the entire data set. The discriminant analysis showed that the most statistically significant parameters of the studied Cypripedium guttatum individuals were the shoot height, the leaf width, flower, staminode, the length and width of dorsal sepal, lateral petal length. All mentioned parameters had $\mathrm{p}<0.05$. The total classification validity was $75.4 \%$. For C. guttatum f. externemaculatum nom. prov. and C. guttatum f. semialbum nom. prov., it was $100 \%$, for C. guttatum $\mathrm{f}$. guttatum $84.2 \%$, for C. guttatum $\mathrm{f}$. rubrosaccos nom. prov. $68.4 \%$, for C. guttatum f. albostriatum nom. prov. $62.5 \%$.

The graphic demonstration of the obtained data of the discriminant analysis is presented in Fig. 4. There are two distinct groups, corresponding to $C$. guttatum f. externemaculatum nom. prov. and C. guttatum f. semialbum nom. prov., respectively. The other three forms (C. guttatum f. guttatum, C. guttatum f. albostriatum nom. prov. and C. guttatum f. rubrosaccos nom. prov.) comprised a separate large cluster, because these forms often demonstrated insignificant differences in terms of their morphometric parameters and consequently displayed transitional forms of flower colouration. This is clearly proved by the results of the discriminant analysis. 
Table 1. Average values of the main morphometric parameters of Cypripedium guttatum individuals in populations of Primorsky Krai

\begin{tabular}{|c|c|c|c|c|c|}
\hline \multirow{2}{*}{ Parameters } & \multicolumn{5}{|c|}{ Average values $(\mathrm{M} \pm \mathrm{m})$ of morphological parameters per each Cypripedium guttatum form $(\mathrm{cm})$} \\
\hline & $\begin{array}{l}\text { C. guttatum } \\
\text { f. guttatum }\end{array}$ & $\begin{array}{c}\text { C. guttatum } \\
\text { f. rubrosaccos }\end{array}$ & $\begin{array}{c}\text { C. guttatum } \\
\text { f. albostriatum }\end{array}$ & $\begin{array}{c}\text { C. guttatum } \\
\text { f. externemaculatum }\end{array}$ & $\begin{array}{l}\text { C. guttatum } \\
\text { f. semialbum }\end{array}$ \\
\hline Shoot height & $20.74 \pm 1.1$ & $18.27 \pm 1.1$ & $19.5 \pm 1.5$ & $24.5 \pm 1.3$ & $14.5 \pm 1.4$ \\
\hline Leaf length & $9.65 \pm 0.3$ & $9.08 \pm 0.2$ & $9.23 \pm 0.3$ & $9.85 \pm 0.4$ & $7.75 \pm 0.2$ \\
\hline Leaf width & $5.18 \pm 0.2$ & $3.99 \pm 0.2$ & $4.47 \pm 0.2$ & $4.0 \pm 0.2$ & $2.92 \pm 0.2$ \\
\hline Bract length & $2.58 \pm 0.2$ & $2.34 \pm 0.1$ & $2.40 \pm 0.1$ & $2.9 \pm 0.3$ & $2.15 \pm 0.2$ \\
\hline Bract width & $1.0 \pm 0.08$ & $0.80 \pm 0.05$ & $0.85 \pm 0.08$ & $1.2 \pm 0.09$ & $0.65 \pm 0.1$ \\
\hline Flower height & $2.36 \pm 0.04$ & $2.23 \pm 0.04$ & $2.33 \pm 0.07$ & $2.2 \pm 0.06$ & $2.25 \pm 0.05$ \\
\hline Flower width & $2.87 \pm 0.08$ & $2.51 \pm 0.1$ & $2.74 \pm 0.1$ & $2.4 \pm 0.1$ & $2.35 \pm 0.05$ \\
\hline Dorsal sepal length & $2.15 \pm 0.05$ & $2.11 \pm 0.05$ & $2.18 \pm 0.07$ & $2.0 \pm 0.1$ & $2.13 \pm 0.1$ \\
\hline Dorsal sepal width & $1.82 \pm 0.05$ & $1.69 \pm 0.05$ & $1.72 \pm 0.06$ & $1.91 \pm 0.01$ & $1.85 \pm 0.1$ \\
\hline Lateral petal length & $1.80 \pm 0.02$ & $1.68 \pm 0.03$ & $1.74 \pm 0.03$ & $1.88 \pm 0.07$ & $1.78 \pm 0.07$ \\
\hline Lateral petal width & $0.72 \pm 0.01$ & $0.68 \pm 0.01$ & $0.72 \pm 0.02$ & $0.78 \pm 0.04$ & $0.72 \pm 0.07$ \\
\hline Lip length & $2.11 \pm 0.03$ & $1.92 \pm 0.04$ & $2.04 \pm 0.04$ & $1.97 \pm 0.02$ & $1.96 \pm 0.03$ \\
\hline Lip width & $1.21 \pm 0.03$ & $1.13 \pm 0.04$ & $1.21 \pm 0.04$ & $1.2 \pm 0.01$ & $1.18 \pm 0.07$ \\
\hline Staminode length & $0.51 \pm 0.01$ & $0.50 \pm 0.01$ & $0.50 \pm 0.01$ & $0.50 \pm 0.01$ & $0.60 \pm 0.01$ \\
\hline Staminode width & $0.41 \pm 0.01$ & $0.38 \pm 0.01$ & $0.41 \pm 0.01$ & $0.40 \pm 0.01$ & $0.40 \pm 0.01$ \\
\hline Diameter of lip orifice & $0.92 \pm 0.02$ & $0.86 \pm 0.03$ & $0.88 \pm 0.03$ & $1.0 \pm 0.04$ & $0.90 \pm 0.01$ \\
\hline
\end{tabular}

Note: $\mathrm{M}$ - arithmetic mean; $\mathrm{m}$ - standard error.

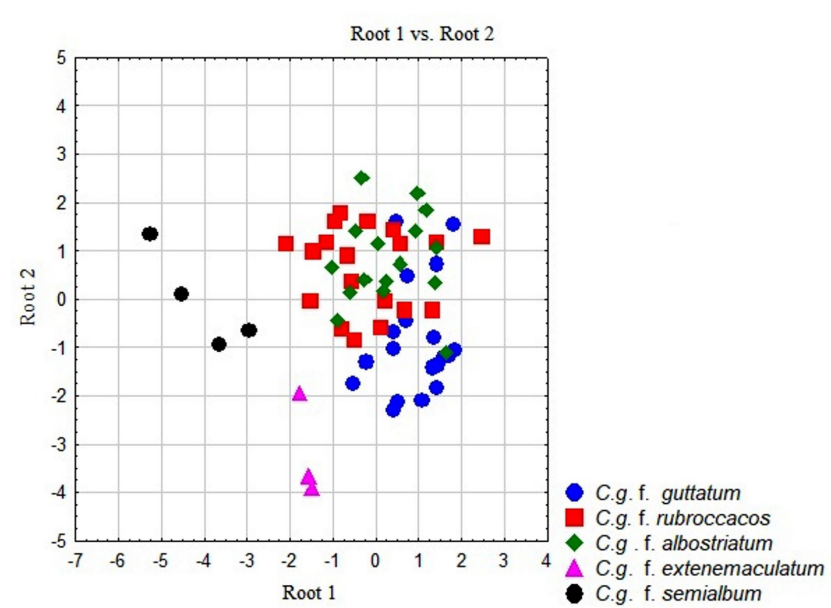

Fig. 4. Sample disposition of the five Cypripedium guttatum forms in the space of the first (Root 1) and second (Root 2) discriminant functions.

\section{Analysis of the infrapopulation variation}

Table 2 shows that populations of Primorsky Krai are characterised by the highest values of infrapopulation variation and rare morph ratio in the population. Whereas the lowest values of infrapopulation variation were found for the Sverdlovsk region, while the lowest values of the rare morph ratio were demonstrated in populations of the Komi Republic.

A cluster analysis was carried out using the similarity index of the studied populations (r). The obtained dendrogram is presented in Fig. 5.

The obtained dendrogram displays that in the Sverdlovsk region, Cypripedium guttatum populations have an isolated position. The populations of Primorsky Krai and the Komi Republic show a remarkable similarity and high degree of infraspecific diversity. It can be explained by the strict protection regime in the Pechora-llych State Nature Reserve (Fig. 6).

Table 2. Parameters of infrapopulation variation in the studied Cypripedium guttatum populations

\begin{tabular}{|l|c|c|c|c|}
\hline \multirow{2}{*}{ Parameters of the infrapopulation variation } & \multicolumn{4}{|c|}{ Russian regions studied } \\
\cline { 2 - 6 } & Primorsky Krai & Sverdlovsk region & Komi Republic & Krasnoyarsky Krai \\
\hline Infrapopulation variation $\left(\mu \pm \mathrm{s}_{\mu}\right)$ & $4.0 \pm 0.03$ & $2.72 \pm 0.04$ & $3.84 \pm 0.01$ & $3.57 \pm 0.02$ \\
\hline Rare morph ratio in the population $\left(\mathrm{h} \pm \mathrm{s}_{\mathrm{h}}\right)$ & $0.2 \pm 0.015$ & $0.09 \pm 0.014$ & $0.04 \pm 0.03$ & $0.06 \pm 0.01$ \\
\hline
\end{tabular}




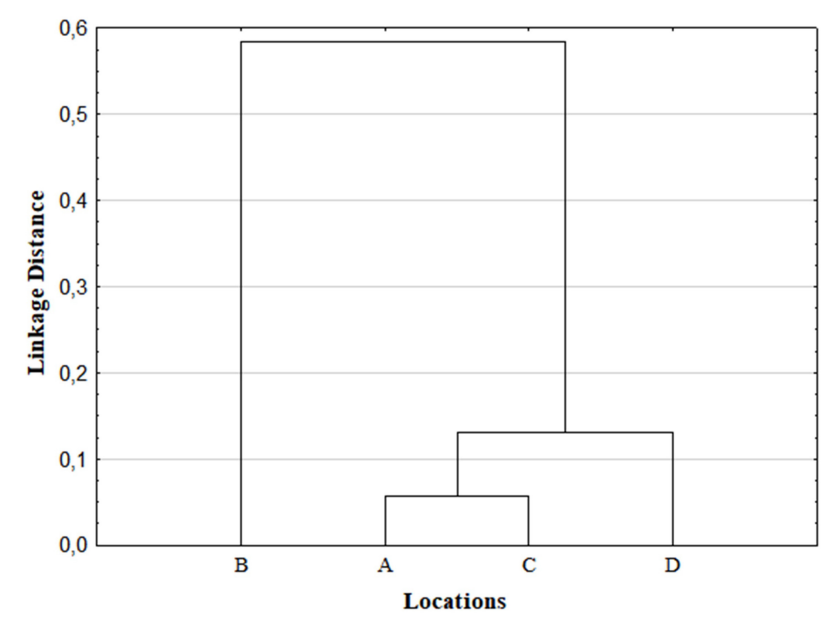

Fig. 5. Dendrogram created on the basis of the similarity index of the studied Cypripedium guttatum populations in each of the Russian region. Designations: A - Primorsky Krai; B - Sverdlovsk region; C - Komi Republic; D - Krasnoyarsky Krai.

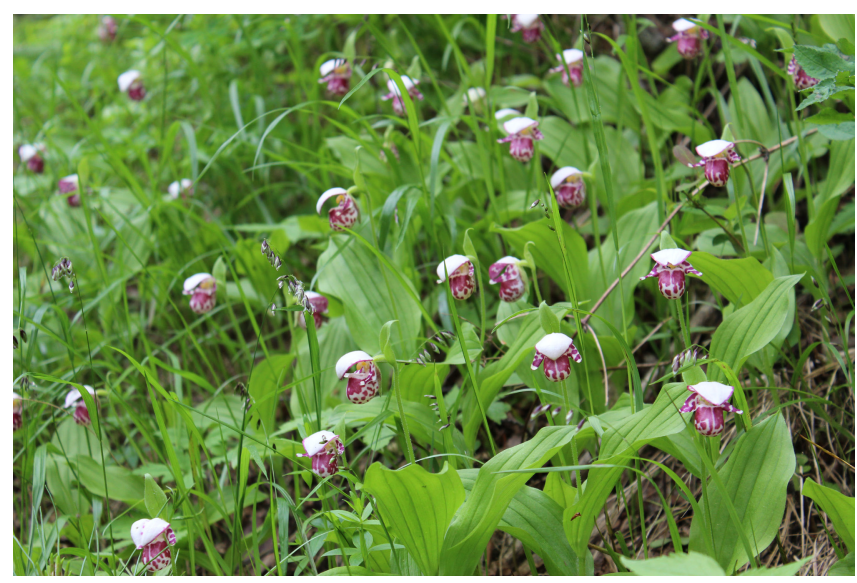

Fig. 6. Population of Cypripedium guttatum in the PechoraIlych State Nature Reserve (Russia).

\section{Discussion}

Flower colouration polymorphism refers to the variation in flower colours within or between natural populations of the same species (Dafni et al., 2020). Although the flower colour is diverse throughout flowering plants, variation within a species is uncommon. Most reported cases of flower colour polymorphisms cover a small colour range, or the colours concerned are not distinguished by pollinators and may simply represent phenotypic plasticity or balance between mutation and selection (Kay, 1978; Waser \& Price, 1981). Cases of polymorphisms have been described for flower colour (Subramaniam \& Rausher, 2000), flower size (Galen et al., 1999), inflorescence size (Dickson \& Petit, 2006), and scent composition (Galen et al., 1999; Thompson et al., 2003).

Orchid species are not characterised by such a high level of flower colour variability as it is recorded within many other species (Gigord et al., 2001). In some orchid species, the unusual flower colour is lighter than typically coloured flowers or even white (Gigord et al., 2001; Salokhin, 2009; Juillet et al., 2010). For example, in Primorsky Krai, some Cypripedium macranthos f. albiflorum (Makino) Ohwi populations were found with completely white flowers. This form is also known as $C$. macranthos var. album Mandl (Averyanov, 1999). White-flowered C. macranthos individuals grow together with typical pink-flowered plants. In an area of $1 \mathrm{~km}^{2}$, plants with a high variation of flower colouration, from white to pink, are observed (Salokhin, 2009).

It is considered that one of the main reasons for polymorphism is the ability to attract competing/alternative pollinators, or to promote pollination efficiency. Generalisation may also be favoured, if the relative abundance of effective pollinators varies annually and in relation to the study site within habitat mosaics (Robertson \& Wyatt, 1990; Galen et al., 1999). Some labour experiments suggested that behavioural pollinator responses to the lack of reward availability might result in a reproductive advantage for rare-colour morphs (Gigord et al., 2001).

The flowers of $C$. guttatum are «kettle traps» without known rewards. Cypripedium is pollinated by various wild bees (Bänziger et al., 2005). Besides, these authors noticed that a group of Cypripedium individuals create a certain pattern attracting pollinators. This may be a combination of green leaves, coloured lips, pale petals and white dorsal sepals (Bänziger et al., 2005).

Although East Asia and North America represent the two major centres of Cypripedium diversity, the former region harbours a higher proportion with 32 species (Li et al., 2011; Tian et al., 2018). At present, the Russian Far East is one of the main diversity centres, where the number of Cypripedium populations remains rather high. This is characterised by well-expressed infraspecific polymorphism and natural hybridisation processes, and speciation can be observed. It can be applied to $C$. guttatum. Our study has revealed that the Far Eastern $C$. guttatum populations have the highest abundance (up to 3000 individuals per $50 \mathrm{~m}^{2}$ ) and the highest number of morph types. However, from the east to the west in Russia, the number of C. guttatum populations decreases. Thus, in the Sverdlovsk region, the density of $C$. guttatum populations was only 100 plants per $50 \mathrm{~m}^{2}$. The obtained data indicate a decrease in plant diversity at the infraspecific level. Furthermore, genetic depletion of the populations is observed, which is associated with the general declining tendency in the abundance of $C$. guttatum in European Russia. This confirms that morphological parameters can vary between individuals from different parts of the species' range. Peripheral populations 
are noted to be non-numerous and more vulnerable to environmental conditions. Peripheral populations are often sparse, fragmented, prone to local extinctions. This makes them demographically and genetically dependent on core habitats and prone to gene flow counteracting local selection (Kawecki, 2008). Therefore, peripheral populations are the most threatened ones and they need special protection measures.

The significant reduction in the number of the wild populations of Cypripedium species is led by the commercial over-collecting of plants, the decorative value of their flowers, their high demand on the plant collector market, as well as their complicated reproductive processes. The major threats are harvesting, breakdown in ecological connections (pollinators, mycorrhiza and chlorophyllous hosts), habitat loss and fragmentation (Swarts \& Dixon, 2009a). As undertaken actions for conservation of their habitats are not sufficient (Swarts \& Dixon, 2009b; Afanasieva et al., 2013; Marakaev, 2016; Biryukova et al., 2018; Fay, 2018) it is necessary to develop a set of more effective measures to protect and restore the number of rare orchid species in Eastern Europe (Feldmann \& Prat, 2011; Swarts \& Dixon, 2009a; Zhang et al., 2014; Shirokov et al., 2014; Shirokov et al., 2017; Swarts \& Dixon, 2017; Fay, 2018; Kolanowska \& Jakubska-Busse, 2020).

As a result of the monitoring of Cypripedium guttatum populations and the study of infraspecific structure, biology and ecology of the rare orchid species, we have developed a specific conservation project for this threatened orchid species. The key project objectives are presented below.

- Study of natural Cypripedium guttatum populations with the aim of monitoring and identifying infraspecific polymorphism and new locations of this rare orchid. Seed collection in abundant Cypripedium guttatum populations, without any threat to the population existence, is necessary.

- Seed germination and seedling production in vitro. In the plant micropropagation laboratory, a novel propagation technology has been developed for Cypripedium guttatum and other terrestrial orchids in culture in vitro.

- Seedling adaptation to the conditions of the botanical gardens. On the experimental terrestrial patches of the Botanical Garden of Lobachevsky State University, we developed an agricultural technology for adaptation and cultivation of the material obtained in vitro to the conditions of a ridge culture. An archive bank of Cypripedium guttatum clones was created.

- Re-introduction of rare orchid species into their natural habitats.
All the above mentioned measures are currently being implemented to preserve and increase the number of rare orchids, including Cypripedium guttatum in European Russia. At present, on the basis of the Botanical Garden of Lobachevsky State University, the Centre for the Conservation of Russian Cypripedium species has been created for studying and conserving rare species of the genus Cypripedium.

\section{Conclusions}

We have revealed a considerable infraspecific diversity of Cypripedium guttatum in different parts of the species range in Russia. In terms of the flower colouration, we have distinguished the following five forms of Cypripedium guttatum: C. guttatum f. guttatum, C. guttatum f. rubrosaccos nom. prov., C. guttatum f. albostriatum nom. prov., C. guttatum f. externemaculatum nom. prov., and $C$. guttatum $\mathrm{f}$. semialbum nom. prov. The analysis of morphometric parameters of the orchid individuals has proven that statistically significant morphometric characters in the studied Cypripedium guttatum populations are shoot height, leaf width, flower width, height and width of dorsal sepal and staminode width. The discriminant analysis confirmed the validity of the five identified forms of Cypripedium guttatum. The research data demonstrated a wide variation in morphology of orchid individuals and predominance of different Cypripedium guttatum forms in various regions of Russia. The specific conservation project was developed and suggested to implement for rare orchid species.

\section{Acknowledgements}

The authors express their deepest gratitude to Prokopiy R. Nogovitsin (Oy secondary school, Republic of Yakutia, Russia) for providing a photo of C. guttatum f. albiflorum, and Nikita N. Shtarkman and Dmitriy A. Nefedov (both Botanical Garden of the Lobachevsky State University of Nizhny Novgorod, Russia) for their assistance in conducting field research.

\section{References}

Afanasieva E.A., Galkina M.A., Kazantseva E.S. 2013. Cenopopulation of Cypripedium guttatum Sw. in the Central Yakutia. Vestnik of North-Eastern Federal University 10(4): 11-18. [In Russian]

Averyanov L.V. 1999. Genus Cypripedium (Orchidaceae) in the Russia. Turczaninowia 2(2): 5-40. [In Russian]

Averyanov L.V. 2000. Orchids (Orchidaceae) of the Middle Russia. Turczaninowia 3(1): 30-53. [In Russian]

Bänziger H., Sun H.Q., Luo Y.B. 2005. Pollination of a slippery lady slipper orchid in South-West China: Cypripedium guttatum (Orchidaceae). Botanical Journal of the Linnean Society 148(3): 251-264. DOI: 10.1111/j.1095-8339.2005.00400.x 
Biryukova O.V., Shestakova A.A., Vorotnikov V.P., Bakka S.V. 2018. Rare and protected species of orchids in the Protected Areas of the Nizhny Novgorod region. In: Protection and cultivation of orchids. Nizhny Novgorod: Nizhny Novgorod University. P. 47-48. [In Russian]

Cribb P. 1997. The genus Cypripedium. Portland: Timber Press. 301 p.

Cribb P., Sandison M.S. 1998. A preliminary assessment of the conservation status of Cypripedium species in the wild. Botanical Journal of the Linnean Society 126(1-2): 183190. DOI: 10.1111/j.1095-8339.1998.tb02525.x

Cribb P.J., Kell S.P., Dixon K.W., Barrett R.L. 2003. Orchid conservation: a global perspective. In: K.W. Dixon, S.P. Kell, R.L. Barrett, P.J. Cribb (Eds.): Orchid Con-servation. Kota Kinabalu: Natural History Publications. P. 1-24.

Dafni A., Tzohari H., Ben-Shlomo R., Vereecken N.J., Ne'eman G. 2020. Flower Colour Polymorphism, Pollination Modes, Breeding System and Gene Flow in Anemone coronaria. Plants 9(3): 397. DOI: 10.3390/plants9030397

Dickson C.R., Petit S. 2006. Effect of individual height and labellum colour on the pollination of Caladenia (syn. Arachnorchis) behrii (Orchidaceae) in the northern Adelaide region, South Australia. Plant Systematics and Evolution 262(1): 65-74. DOI: 10.1007/s00606-006-0472-3

Fay M.F. 2018. Orchid conservation: how can we meet the challenges in the twenty-first century? Botanical Studies 59: 16. DOI: 10.1186/s40529-018-0232-z

Feldmann P., Prat D. 2011. Conservation recommendations from a large survey of French orchids. European Journal of Environmental Sciences 1(2): 18-27. DOI: 10.14712/23361964.2015.43

Flora of North America North of Mexico. Vol. 26: Magnoliophyta: Liliidae: Liliales and Orchidales. New York: Oxford University Press, 2002. 752 p.

Galen C. 1999. Why Do Flowers Vary? The functional ecology of variation in flower size and form within natural plant populations. Bioscience 49(8): 631-640. DOI: $10.2307 / 1313439$

Gigord L., Macnair M., Smithson A. 2001. Negative frequencydependent selection maintains a dramatic flower colour polymorphism in the rewardless orchid Dactylorhiza sambucina (L.) Soò. Proceedings of the National Academy of Sciences of the United States of America 98(11): 6253-6255. DOI: 10.1073/pnas.111162598

Hardion L., Verlaque R., Vorontsova M.S., Combroux I., Chen C.W., Takamizo T., Vila B. 2017. Does infraspecific taxonomy match species evolutionary history? A phylogeographic study of Arundo formosana (Poaceae). Botanical Journal of the Linnean Society 183(2): 236-249. DOI: 10.1093/botlinnean/bow006ff

Juillet N., Delle-Vedove R., Dormont L., Schatz B., Pailler T. 2010. Differentiation in a tropical deceptive orchid: Colour polymorphism and beyond. Plant Systematics and Evolution 289(3): 213-221. DOI: 10.1007/s00606-010-0344-8

Kawecki T.J. 2008. Adaptation to Marginal Habitats. Annual Review of Ecology, Evolution, and Systematics 39: 321342. DOI: 10.1146/annurev.ecolsys.38.091206.095622

Kay Q.O.N. 1978. The Pollination of Flowers by Insects. Linnean Society Symposium Series 6: 175-190.
Kolanowska M., Jakubska-Busse A. 2020. Is the lady'sslipper orchid (Cypripedium calceolus) likely to shortly become extinct in Europe? - Insights based on ecological niche modelling. PLOS ONE 15(1): e0228420. DOI: 10.1371/journal.pone.0228420

Kopowitz H. 2005. Orchid conservation and CITES. In: Raynal-Roque, A. Roguenant, D. Prat (Eds.): Proceedings of the 18 ${ }^{\text {th }}$ World Orchid Conference (11-20 March 2005, Dijon-France). Turriers: Naturalia. P. 301-305.

Li J.H., Liu Z.J., Salazar G.A., Bernhardt P., Perner H., Tomohisa Y., Jin X.H., Chung S.W., Luo Y.B. 2011. Molecular phylogeny of Cypripedium (Orchidaceae: Cypripedioideae) inferred from multiple nuclear and chloroplast regions. Molecular Phylogenetics and Evolution 61(2): 308-320. DOI: 10.1016/j.ympev.2011.06.006

Marakaev O.A. 2016. Orchids (Orchidaceae Juss.) at especially protected natural territories of Yaroslavl oblast. Proceedings of Samara Scientific Centre RAS 18(2): 136-140. [In Russian]

Red Data Book of the Russian Federation (plants and fungi). Moscow: KMK Scientific Press Ltd., 2008. 855 p. [In Russian]

Robertson J.L., Wyatt R. 1990. Evidence for pollination ecotypes in the yellow-fringed orchid, Platanthera ciliaris. Evolution 44(1): 121-133. DOI: 10.1111/j.1558-5646.1990.tb04283.x

Salokhin A.V. 2009. Orchidaceae of the Far East (taxonomy, chemical composition and use possibilities). $\mathrm{PhD}$ Thesis. Vladivostok. 24 p. [In Russian]

Salokhin A.V. 2018. Features of the distribution of orchids in the Far East. In: Protection and cultivation of orchids. Nizhny Novgorod: Nizhny Novgorod University. P. 74-75. [In Russian]

Shirokov A.I., Salokhin A.V., Syrova V.V., Kryukov L.A. 2014. Results of creating a collection of the Cypripedium genus at the UNN Botanical Garden Research Institute. Vestnik of Lobachevsky University of Nizhni Novgorod 3(3): 150-153. [In Russian]

Shirokov A.I., Syrova V.V., Kryukov L.A., Shestakova A.A. 2017. Reintroduction of Dactylorhiza incarnata (L.) Soó into the natural habitats of the European Russia. Applied Ecology and Environmental Research 15(1): 445-455. DOI: 10.15666/aeer/1501_445455

Singchi C., Zhongjian L., Lijun C., Liqiang L. 2013. The Genus Cypripedium in China. Beijing: Science Press. 317 p.

Stuessy T.F. 2009. Plant Taxonomy: The Systematic Evaluation of Comparative Data. New York: Columbia University Press. 568 p.

Subramaniam B., Rausher M.D. 2000. Balancing selection on a floral polymorphism. Evolution 54(2): 691-695. DOI: 10.1111/j.0014-3820.2000.tb00070.x

Swarts N.D., Dixon K.W. 2009a. Perspectives on orchid conservation in botanic gardens. Trends in Plant Science 14(11): 590-598. DOI: 10.1016/j.tplants.2009.07.008

Swarts N.D., Dixon K.W. 2009b. Terrestrial orchid conservation in the age of extinction. Annals of Botany 104(3): 543-556. DOI: 10.1093/aob/mcp025

Swarts N.D., Dixon K.W. 2017. Conservation methods for terrestrial orchids. Plantation: J. Ross Publishing. 240 p.

Thompson J.D., Chalchat J.C., Michet A., Linhart Y.B., Ehlers B. 2003. Qualitative and quantitative varia- 
tion in monoterpene co-occurrence and composition in the essential oil of Thymus vulgaris chemotypes. Journal of Chemical Ecology 29(4): 859-880. DOI: 10.1023/A:1022927615442

Thomson S.A., Pyle R.L., Ahyong S.T., Alonso-Zarazaga M., Ammirati J., Araya J.F., Ascher J.S., Audisio T.L., Azevedo-Santos V.M., Bailly N., Baker W.J., Balke M., Barclay M.V.L., Barrett R.L., Benine R.C., Bickerstaff J.R.M., Bouchard P., Bour R., Bourgoin T., Boyko C.B., Breure A.S.H., Brothers D.J., Byng J.W., Campbell D., Ceríaco L.M.P., Cernák I., Cerretti P., Chang C.H., Cho S., Copus J.M. et al. 2018. Taxonomy based on science is necessary for global conservation. PLoS Biology 16(3): e2005075. DOI: 10.1371/journal.pbio.2005075

Tian H.Z., Han L., Zhang J., Li X., Kawahara T., Yukawa T., López-Pujol J., Kumar P., Chung M.G., Chung M.Y. 2018. Genetic diversity in the endangered terrestrial orchid Cypripedium japonicum in East Asia: Insights into population history and implications for conservation. Scientific Reports 8(1): 6467. DOI: $10.1038 / \mathrm{s} 41598-018-24912-\mathrm{Z}$

Vakhrameeva M.G., Tatarenko I.V., Varlygina T.I., Torosyan G.K., Zagulskii M.N. 2008. Orchids of Russia and Adjacent Countries (within the borders of the former USSR). Liechtenstein: A.R.G. Gantner Verlag Ruggell. 690 p.

Ward J.H. 1963. Hierarchical grouping to optimize an objective function. Journal of the American Statistical Association 58(301): 236-244.

Waser N.M., Price M.V. 1981. Pollinator Choice and Stabilizing Selection for Flower Color in Delphinium nelsonii. Evolution 35(2): 376-390. DOI: 10.1111/ j.1558-5646.1981.tb04896.x

Zhang Y.H., Sun H. 2006. Cypripedium bouffordianum (Orchidaceae), a new species from western Sichuan, China. Annales Botanici Fennici 43(6): 481-483.

Zhang Y., Zhao S., Liu D., Zhang Q., Cheng J. 2014. Flowering phenology and reproductive characteristics of Cypripedium macranthos (Orchidaceae) in China and their implication in conservation. Pakistan Journal of Botany 46(4): 1303-1308.

Zhengyi W., Raven P.H., Deyuan H. (Eds.). 2009. Flora of China: Orchidaceae. St. Louis: Science Press, Beijing \& Missouri Botanical Garden Press. 570 p.

Zhivotovsky L.A. 1982. Indicators of population variability by polymorphic features. In A.V. Yablokov (Ed.): Population Phenetics. Moscow: Nauka. P. 38-45. [In Russian]

\title{
ВНУТРИВИДОВОЙ ПОЛИМОРФИЗМ СУРRIPEDIUM GUTTATUM В РАЗНЫХ ЧАСТЯХ АРЕАЛА В РОССИИ В СВЯЗИ С ВОПРОСАМИ ОХРАНЫ
}

\author{
А. И. Широков ${ }^{1, *}$, В. В. Сырова ${ }^{1}$, А. В. Салохин ${ }^{2}$, \\ И. Н. Маркелов ${ }^{1}$ Е. В. Андронова ${ }^{3}$, Е. В. Ганюшкина ${ }^{1}$ \\ ${ }^{1}$ Нижегородский государственный университет им. Н.И. Лобачевского, Россия \\ *e-mail: aishirokov@mail.ru \\ ${ }^{2}$ Ботанический сад-институт ДВО РАН, Россия \\ e-mail:al-xv@mail.ru \\ ${ }^{3}$ Ботанический институт им. В.Л. Комарова РАН, Россия \\ e-mail: elena.andronova@mail.ru
}

\begin{abstract}
Проблема охраны редких и исчезающих видов в современных условиях очень остро. Особое место в этой проблеме занимают представители семейства Orchidaceae. Целью данной работы являлось изучение полиморфности цветков Cypripedium guttatum в природных популяциях в разных частях ареала в России. В ходе изучения природных популяций в Приморском крае, Свердловской области, Республике Коми и Красноярском крае, было выделено пять форм Cypripedium guttatum по окраске цветков. Сравнительный анализ внутривидовой структуры выявил, что наибольшее разнообразие форм наблюдается в популяциях Приморского края, а наименьшее - в популяциях Свердловской области. Дискриминантный анализ показал, что наиболее статистически значимыми признаками для особей разных форм Cypripedium guttatum являются высота побега, ширина листа, ширина цветка, высота и ширина паруса, ширина стаминодия. Анализ популяционной изменчивости проводился по трем показателям: среднее число морф в популяции, доля редких морф в популяции, показатель сходства популяций. При проведении мониторинга популяций, исследования внутривидовой структуры, особенностей биологии и экологи редких видов, был разработан комплексный метод сохранения редких видов орхидных.
\end{abstract}

Ключевые слова: Orchidaceae, дискриминантный анализ, мониторинг, морфометрические показатели, окраска цветка, редкий вид 